\title{
CHANGES IN USE LAND OF DEFENSE IN THE PROCESS OF LAND REFORM IN UKRAINE
}

\author{
A.. Melnichuk, graduate student, \\ State Ecology Academy of Postgraduate Education and Management \\ E-mail:nnieco@ukr.net
}

The changes in the quantitative and qualitative state of use of defense lands in the period from 1990 to 2016 were researched.

As a result, it became known that since 1990 the total area of defense lands has decreased by 59.7\%, and from 2010 to 20167 by $0.4 \%$.

The lands of the Ministry of Defense in the category of defense lands constitute 339.8 thousand hectares or $84.9 \%$ of the total area, the Ministry of Internal Affairs - 11.8 thousand hectares or 2.9\%, the National Guard - 10,0 thousand hectares or $2.5 \%$, the State Committee for the Protection of the State Border of 6.8 thousand hectares or 1.7\%, the Society for the Defense of Ukraine 3.1 thousand hectares or $0.8 \%$, other military formations - 10.7 thousand hectares or $2.7 \%$.

Established, that significant changes that took place in the land use of defense did not increase of ecological, economic and social security, and, consequently, the safety of the life of the population of Ukraine.

Keywords. Land use of defense, land of defense, land and property relations.

\section{Formulation of the problem:}

Accordance with the Land code ofUkraine (2001), the lands fund is divided into ninecategories: earth of housing and public building, earth of theagricultural setting, earth of industry, transport, connection, energy, defensive and other setting, earth of the natureprotection setting, earth of the recreational setting, earth ofthe health setting, earth of the historic and cultural setting, earth of the forestry setting and earth of waterfund [1]. Each of categories of the landed fund has thebacklogs. These categories and numerous subcategoriescreate founding for determination of rights and duties, structure of land-tenure and management the 
landedresources, statistical accounting and distribution ofadministrative duties between public institutions and organslocal.

The purpose of the article is to highlight the quantitative and qualitative changes in the land use of the defense since 1990 by 2016

Research results. According to the data of the state land cadaster (form 6earth), by the year 2016 [2] the land of defense is 400,3 hectares (Table 2.1) or $0,7 \%$ of the territory of the state. Thus, the structure of the land fund of Ukraine shows that a large part of the country's territory were occupied by agricultural land - $60.8 \%$, forestland - $14.3 \%$, built-up land $-3.3 \%$.

As the data analysis (Table 2.1) shows, since 1990, the total land area of defense has decreased by $59.7 \%$, and from 2010 to 2016 by $0.4 \%$.

The lands of the Ministry of Defense within the category of defense lands make up 339.8 thousand hectares or $84.9 \%$ of the total area (Table 2.2), the Ministry of Internal Affairs - 11.8 thousand hectares or 2.9\%, the national guard 10,0 thousand hectares or $2.5 \%$, the State Committee for the Protection of the State Border of 6.8 thousand hectares or $1.7 \%$, the Society for the Defense of Ukraine 3.1 thousand hectares or $0.8 \%$, other military formation -10.7 thousand hectares or $2.7 \%$.

In land use defense has undergone significant changes after the occupation of the Autonomous Republic of Crimea by Russia. In particular, the area of defense lands decreased to 362.2 thousand hectares or 9.5\% (Table 2.3). 


\section{Trends in the distribution of land by category in the period $1990-2016$}

\begin{tabular}{|c|c|c|c|c|c|c|c|c|c|c|}
\hline \multirow{2}{*}{$\begin{array}{c}\text { № } \\
\Pi / \Pi\end{array}$} & \multirow{2}{*}{$\begin{array}{c}\text { Categories of lands, groups landowners and land } \\
\text { users }\end{array}$} & \multicolumn{5}{|c|}{ Year, thous. hect } & \multicolumn{2}{|c|}{$\begin{array}{c}2010 \text { to } \\
2016(+;-)\end{array}$} & \multicolumn{2}{|c|}{$\begin{array}{c}1990 \text { to2016 } \\
(+;-)\end{array}$} \\
\hline & & 1990 & 2000 & 2010 & 2016 & $\begin{array}{l}\text { B } \% \\
2016 \mathrm{p} .\end{array}$ & $\begin{array}{c}\text { тис. } \\
\text { га }\end{array}$ & $\%$ & тис. га & $\%$ \\
\hline 1 & Agricultural lands & 47294,0 & 40763,8 & 37561,1 & 36702,4 & 60,8 & 858,7 & $-2,3$ & $\begin{array}{c}- \\
10591,6\end{array}$ & $-22,4$ \\
\hline 2 & Residential and public landdevelopmen & 1928,3 & 723,5 & 1606,1 & 1990,1 & 3,3 & 384,0 & 23,9 & 61,8 & 3,2 \\
\hline 3 & Industrial and other enterprises & 408,6 & 303,4 & 585,7 & 539,8 & 0,9 & $-45,9$ & $-7,8$ & 131,2 & 32,1 \\
\hline 4 & $\begin{array}{l}\text { Enterprises and organizations transport, } \\
\text { communications }\end{array}$ & 585,6 & 493,3 & 644,0 & 643,5 & 1,1 & $-0,5$ & $-0,1$ & 57,9 & 9,9 \\
\hline 5 & $\begin{array}{l}\text { Bases, enterprises, organizations, institutions of } \\
\text { defense }\end{array}$ & 992,1 & 451,2 & 402,1 & 400,3 & 0,7 & $-1,8$ & $-0,4$ & $-591,8$ & $-59,7$ \\
\hline 6 & $\begin{array}{l}\text { Organizations, enterprises and establishments of } \\
\text { nature protection, recreation, recreation and } \\
\text { historical and cultural purposes }\end{array}$ & 204,7 & 414,1 & 480,5 & 513,7 & 0,9 & 33,2 & 6,9 & 309,0 & 151,0 \\
\hline 7 & Forest lands & 6591,9 & 8173,5 & 8588,8 & 8653,7 & 14,3 & 64,9 & 0,8 & 2061,8 & 31,3 \\
\hline 8 & Earth Water Fund & 296,4 & 456 & 260,9 & 255,8 & 0,4 & $-5,1$ & $-2,0$ & $-40,6$ & $-13,7$ \\
\hline 9 & From all categories of land stock & 2053,4 & 8576,0 & 10652,0 & 10738,9 & 17,8 & 86,9 & 0,8 & 8685,5 & 423,0 \\
\hline 10 & Land of other purpose & - & - & 108,9 & & & & & & \\
\hline & Total land & 60355,0 & 60354,8 & 60354,8 & 60354,8 & 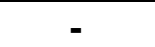 & - & - & - & - \\
\hline
\end{tabular}

* Developed according to the data of the state land cadaster (form 6-earth) 


\section{Characteristics of land use of parts, enterprises, organizations, institutions, educational institutions as of $\mathbf{2 0 1 6}$}

\begin{tabular}{|l|c|c|}
\hline \multirow{2}{*}{ Types of land use } & \multicolumn{2}{c|}{ Area. } \\
\cline { 2 - 3 } & thous. hec. & $\%$ \\
\hline \multicolumn{1}{|c|}{1} & 2 & 3 \\
\hline Ministry of Defense & 339,8 & 84,9 \\
\hline Ministry of the Interior affairs & 11,8 & 2,9 \\
\hline National guard & 10,0 & 2,5 \\
\hline State Committee for the Protection of the State Border & 6,8 & 1,7 \\
\hline Society for the Defense of Ukraine & 3,1 & 0,8 \\
\hline Foreign military formations & $18,2^{* *}$ & 4,5 \\
\hline Other military formations & 10,7 & 2,7 \\
\hline Total, thousand hectares & $\mathbf{4 0 0 , 3}$ & $\mathbf{1 0 0 , 0}$ \\
\hline
\end{tabular}

* Developed according to the data of the state land cadaster (form 6-earth).

** Taking into account the territory of the Autonomous Republic of Crimea.

3. Land units, enterprises, organizations, institutions, educational institutions in the context of regions of Ukraine as of 01.01 .2016 , (ths. $\mathrm{H}$ )

\begin{tabular}{|l|c|c|c|c|}
\hline \multirow{2}{*}{$\begin{array}{c}\text { The name of the administrative- } \\
\text { territorial units }\end{array}$} & \multicolumn{2}{|c|}{ Total } & \multicolumn{2}{c|}{ built } \\
\cline { 4 - 5 } Vinnitsaregion & \multicolumn{2}{|c|}{ тис. га } & в $\%$ & тис. га \\
& 6,0 & 1,7 & 1,9 & в \% \\
\hline Volynregion & 7,8 & 2,2 & 1,7 & 1,4 \\
\hline Dnipropetrovskregion & 18,3 & 5,1 & 4,1 & 3,7 \\
\hline Donetskregion & 1,9 & 0,5 & 1,8 & 1,6 \\
\hline Zhytomyrregion & 33,4 & 9,2 & 4,5 & 4,1 \\
\hline Transcarpathianregion & 9,6 & 2,7 & 1,7 & 1,6 \\
\hline Zaporozhyeregion & 2,9 & 0,8 & 2,1 & 1,9 \\
\hline Ivano-Frankivskregion & 4,2 & 1,2 & 1,3 & 1,2 \\
\hline Kievskayaregion & 25,3 & 7,0 & 4,0 & 3,6 \\
\hline Kirovogradskayaregion & 6,8 & 1,9 & 2,9 & 2,6 \\
\hline Luganskregion & 1,3 & 0,4 & 1,1 & 1,0 \\
\hline Lvivregion & 61,6 & 17,0 & 5,2 & 4,7 \\
\hline Nikolaevregion & 41,7 & 11,5 & 28,7 & 26,2 \\
\hline Odesaregion & 14,9 & 4,1 & 10,0 & 9,1 \\
\hline Poltavaregion & 3,3 & 0,9 & 3,3 & 3,0 \\
\hline
\end{tabular}




\begin{tabular}{|l|c|c|c|c|} 
Rivneregion & 33,0 & 9,1 & 1,7 & 1,6 \\
\hline Sumyregion & 3,3 & 0,9 & 0,8 & 0,7 \\
\hline Ternopilregion & 1,1 & 0,3 & 0,7 & 0,6 \\
\hline Kharkivregion & 15,0 & 4,1 & 5,6 & 5,1 \\
\hline Khersonregion & 5,8 & 1,6 & 5,6 & 5,1 \\
\hline Khmelnitskyregion & 7,1 & 2,0 & 4,2 & 3,8 \\
\hline Cherkassyregion & 7,5 & 2,1 & 1,4 & 1,3 \\
\hline Chernivtsiregion & 1,1 & 0,3 & 1,0 & 0,9 \\
\hline Chernihivregion & 47,8 & 13,2 & 13,4 & 12,2 \\
\hline Kiev & 1,5 & 0,4 & 1,1 & 1,0 \\
\hline Ukraine & $\mathbf{3 6 2 , 2}$ & $\mathbf{1 0 0 , 0}$ & $\mathbf{1 0 9 , 6}$ & $\mathbf{1 0 0 , 0}$ \\
\hline
\end{tabular}

of built-up lands ranges from 0.7 to 28.7 percent. The share of built-up land in those regions where military units are located.

As statistics show, the legislation of Ukraine defines the land of defense through their composition, while proceeding from the actual subordination of land use relations (which, in our opinion, is not consistent with the provisions on the division of land in the category "for the main purpose" of Art. 19 ZKU). According to research A.M. Tretyak the third [3] land is, firstly, the subject of interest of all, without exception, categories, groups and strata of the population; This is a complex moment of nationwide, group (departmental, territorial) and individual (private) mutual claims. Accordingly, the formation and operation of land-use in the field of defense has a universal universalmultisubject, multidimensional and multi-level nature. Secondly, the land as an economic category participates in the reproduction process and in areas of distribution, exchange and consumption. Thus, through the taxation mechanism, land utilization implements public functions of redistribution of land rent. Land use, as an economic category was determined by the nature of social production, a specific social type of economy in which the land functions as a means of production. The tool for a correct 
understanding of the economic essence of land use in the field of defense is the nature of interests as objective (social) and subjective (personal consumption).

The characteristics of the distribution of land resources of Ukraine in terms of their functional and permitted use as of the period 2001-2016 has given in Table 2.4. According to the data of the table, the share of land resources for the functional use of the land fund of Ukraine is the forested areas of $36.1 \%$, built-up lands $32.9 \%$, agricultural land $14.1 \%$, marshes and water $12.8 \%$.

\section{Trends in the distribution of land defense by their functional use}

\begin{tabular}{|c|c|c|c|c|}
\hline \multirow{4}{*}{$\begin{array}{l}\text { Types of functional and permitted use } \\
\qquad \\
1\end{array}$} & \multicolumn{3}{|c|}{ years } & \multirow{4}{*}{$\begin{array}{l}+,- \text { в } \% \\
2001 \text { до } \\
2016 \mathrm{p} . \\
5\end{array}$} \\
\hline & \multirow{2}{*}{\multicolumn{2}{|c|}{\begin{tabular}{l|l}
\multicolumn{1}{|c|}{2001} & \\
area, thousand \\
hectares
\end{tabular}}} & 2016 & \\
\hline & & & in $\%$ & \\
\hline & 2 & 3 & 4 & \\
\hline Agricultural land & 457,1 & 56,6 & 14,1 & $-87,6$ \\
\hline Agricultural territory & 61,9 & 56,0 & 14,0 & $-9,5$ \\
\hline including: arable land & 17,7 & 1,9 & 0,5 & $-89,3$ \\
\hline perennial plantations & 0,2 & 0,1 & 0,0 & $-50,0$ \\
\hline hayfields and pastures & 43,7 & 34,6 & 8,6 & $-20,8$ \\
\hline Under the yards, roads and runs & $*$ & 0,6 & 0,1 & \\
\hline Woods & 138,4 & 144,6 & 36,1 & 4,5 \\
\hline including forest lands & 134,7 & 141,1 & 35,2 & 4,8 \\
\hline brushwood's & 3,7 & 3,5 & 0,9 & $-5,4$ \\
\hline from all forest lands: for the production of wood & $*$ & 55,5 & 13,9 & \\
\hline $\begin{array}{l}\text { for a protective, environmental and biological } \\
\text { purpose }\end{array}$ & $*$ & 53,2 & 13,3 & \\
\hline Built land & 168,9 & 131,5 & 32,9 & $-22,1$ \\
\hline including: living land & 2,5 & 1,5 & 0,4 & $-40,0$ \\
\hline industrial & 6,2 & 4,2 & 1,0 & $-32,3$ \\
\hline opendevelopment & $*$ & 0,4 & 0,1 & \\
\hline public appointment & $*$ & 111,1 & 27,8 & \\
\hline mixed use & $*$ & 1,8 & 0,4 & \\
\hline $\begin{array}{l}\text { transport, } \\
\text { communicationandtechnicalinfrastructure }\end{array}$ & 12,5 & 12,3 & 3,1 & $-1,6$ \\
\hline for recreation & 0,5 & 0,4 & 0,1 & $-20,0$ \\
\hline Swamps & 4,1 & 48,7 & 12,2 & 1087,8 \\
\hline Water & 2,9 & 2,6 & 0,6 & $-10,3$ \\
\hline $\begin{array}{l}\text { Open lands without vegetation or with } \\
\text { insignificant vegetation }\end{array}$ & 80,6 & 12,9 & 3,2 & $-84,0$ \\
\hline Total & 457,1 & 400,3 & 100,0 & $-12,4$ \\
\hline
\end{tabular}

* Developed by the author according to the state land cadastre (form 6-earth) 
During this period, from 2001 to 2016, substantial changes has made in the distribution of land resources for their functional use. In particular, there was a significant reduction in the area of agricultural land (87.6\%) as a result of the transfer of auxiliary agricultural enterprises to the Ministry of Agrarian Policy and food and built-up land (22.1\%), especially housing, and territorial communities.

At the same time, it is alarming that the land of the forest fund and public service does not allocate land for military landfills and military units, as this is a land use of a special regime, which, as regimens, requires the establishment of special zones of special regime.

The indicated has a significant impact on the ecological, economic and social safety of the life of the population. For example, in tabl. 2.5 gives an assessment of the tendencies of distribution of land resources of Ukraine for their ecological orientation for the period from 01.01.2001 to 01.01.2016, shows that, although there was a significant redistribution of land according to the ecological orientation, this did not significantly affect the ecological safety of land use, and accordingly, and vital activity of the population.

5 Estimation of the distribution of land resources of Ukraine for themecological orientation for the period from 01.01.2001 to 01.01.2016 years

\begin{tabular}{|c|c|c|c|c|c|c|}
\hline \multirow{2}{*}{$\begin{array}{c}\text { Types of land use for } \\
\text { their environmental } \\
\text { orientation }\end{array}$} & \multicolumn{2}{|c|}{ Asof 01.01.2001 } & \multicolumn{2}{|c|}{ Asof 01.01.2016 } & \multirow[b]{2}{*}{$\begin{array}{l}+,-2001 \text { to } \\
2016 \text { in } \%\end{array}$} & \multirow{2}{*}{$\begin{array}{l}\text { The coefficient } \\
\text { of environmental } \\
\text { impact of the } \\
\text { land on the } \\
\text { adjacent land }\end{array}$} \\
\hline & тис. га & $\%$ & тис. га & $\%$ & & \\
\hline Constructedland & 168,9 & 37,0 & 131,5 & 32,9 & $-22,1$ & 1,27 \\
\hline Arable land & 17,7 & 3,9 & 1,9 & 0,5 & $-89,3$ & 0,87 \\
\hline Perennialplantations & 0,2 & 0,0 & 0,1 & 0,02 & $-50,0$ & 1,47 \\
\hline $\begin{array}{l}\text { Sine-branches and } \\
\text { pastures }\end{array}$ & 43,7 & 9,6 & 34,6 & 8,6 & $-20,8$ & 1,71 \\
\hline $\begin{array}{l}\text { Forests and } \\
\text { brushwood's }\end{array}$ & 138,4 & 30,3 & 144,6 & 36,1 & 4,5 & 2,29 \\
\hline $\begin{array}{l}\text { Under water and } \\
\text { swamps }\end{array}$ & 7 & 1,5 & 51,3 & 12,8 & 632,9 & 2,93 \\
\hline $\begin{array}{l}\text { Open lands without } \\
\text { vegetation or with } \\
\text { insignificant vegetation }\end{array}$ & 80,6 & 17,6 & 12,9 & 3,2 & $-84,0$ & 1,27 \\
\hline Total & 457,1 & 100,0 & 400,3 & 100,0 & $-12,4$ & \\
\hline
\end{tabular}

Source: calculated according to the form of the sixth State Geocadaster for the relevant year and [4]. 
As the magnitude of the ecological impact of land on adjoining land indicates, the most positive influence is the land under water and marshes $(\mathrm{Ke}=$ 2.93) and forests and shrubs $($ Kee $=2.29)$. The most negative effect on the ecological state of land use is the arable land $(\mathrm{Ke}=0,87)$.

Conclusion. During the years of Ukraine's independence, significant changes have taken place in land use of defense. In particular, its area has decreased since 1990 by 591.8 thousand hectares or 59.7\%, and from 2010 to 2016 by 597 thousand hectares or by $0.4 \%$. The lands of the Ministry of Defense in the category of defense lands make up 339.8 thousand hectares or $84.9 \%$ of the total area, the Ministry of Internal Affairs - 11.8 thousand hectares or 2.9\%, the national guard - 10,0 thousand hectares or $2.5 \%$, the State Committee for the Protection of the State Border of 6.8 thousand hectares or 1.7\%, the Society for the Defense of Ukraine -3.1 thousand hectares or $0.8 \%$, other military formations - 10.7 thousand hectares or $2.7 \%$. Characteristics of the distribution of land of defense by their functional use state shows that their specific weight for functional use is the forested area of $36.1 \%$, built-up lands $32.9 \%$, agricultural land $14.1 \%$, marshes and water $12.8 \%$. It has established that the changes that took place in land use defense did not affect the increase of ecological, economic and social security, and, consequently, safety of life of the population.

\section{References:}

1. Land Code of Ukraine(2002).Avalableat: http://zakon2.rada.gov.ua/ᄀlaws/show/2874\%D0\%B0-07.

2. State Land Cadastre (Form 6-Land)01.01.2016.

3. Tretiak A.M. (2012). Ekolohiiazemlekorystuvannia: teoretykometodolohichniosnovyformuvanniataadministruvannia: monohrafiia[Tretyak A.M. Ecology of land use: theoretical and methodological foundations of formation and administration: monograph]Kherson, 438 s. (Hrin D.S.). s. 13-14. 
4. Tretyak A.M., Shkvyr M.I (2001).

Metodychnirekomendaciyiocinkyekologichnoyistabilnostiagrolandshaftiv ta silskogospodarskogozemlekory`stuvannya[Methodical recommendations for assessing the ecological stability of agro-landscapes and agricultural land use] - In-t zemleustroyu UAAN, 15.

\section{А.Ю. Мельничук}

Тенденції змін землекористування оборони в процесі здійснення земельної реформи в Україні

Анотація. Досліджено зміни кількісного $і$ якісного стану землекористування оборони в період з 1990 р. по 2016 р. В результаті чого стало відомо, щьо з 1990 р. зменшилася загальна площа земель оборони на 59,7\%, аз 2010 p. по 2016 р. на 0,4\%.

Землі Міністерства оборони в складі категорї земель оборони складають - 339,8 тис. га або 84,9\% від загальної площі (табл. 2.2), Міністерство внутрішніх справ - 11,8 тис. га або 2,9\%, Начіональна гвардія - 10,0 тис. га або 2,5\%, Державний комітет у справах охорони державного кордону - 6,8 тис. га або 1,7\%, Товариство сприяння обороні Украӥни - 3,1 тис. га або 0,8\%, інші військові формування - 10,7 тис. га або 2,7\%.

Встановлено, щуо суттєві зміни, які пройшли у землекористуванні оборони, не вплинули на підвищення екологічної, економічної та соиіальної його безпеки, а відповідно і безпеки життєдіяльності населення України.

Ключові слова. Землекористування оборони, землі оборони, земельні відносини, функиіональне використання земель. 


\section{Мельничук А.Ю.}

\section{Тенденции изменения землепользования обороны в процессе}

\section{проведения земельной реформы в Украине}

Аннотащия. Исследованы изменения количественного и качественного состояния землепользования обороны в течение 1990-2016 г2. В результате чего стало известно, что с 1990 г. Прошло уменьщения общей площуади земель обороны на 59,7\%, а с 2010 г. По 2016 на 0,4\%.

Земли министерства обороны в составе категории земель оборонь составляют - 339,8 тыс. Га или 84,9\% от общей площади (табл. 2.2), министерство внутренних дел - 11,8 тыс. Га или 2,9\%, наџиональная гвардия - 10 тыс. га или 2,5\%, государственный комитет по делам охраны государственной гранищь - 6,8 тыс. га или 1,7\%, общество содействия обороне Украины - 3,1 тыс. га или 0,8\%, другие военные формирования - 10,7 тысс. га или $2,7 \%$.

Установлено, что существенные изменения, которые прошли в землепользовании обороны, не повлияли на повышение экологической, экономической и социальной его безопасности, а соответственно и безопасности жизнедеятельности населения страны.

Ключевые слова. Землепользования обороны, земли обороны, земельные отномения, функииональное использование земель. 